\title{
DETERMINANTS AFFECTING PROFITABILITY AND STOCK RETURNS FOR SMALLER BANKS LISTED ON THE INDONESIA STOCK EXCHANGE
}

\author{
Ferry Ardiansyaha $^{*}$, Hermanto Siregar**), Dedi Budiman Hakim**), Mulya Siregar*) \\ *) School of Business, IPB University \\ Jl. Pajajaran, Bogor 16151, Indonesia \\ **) Department of Economics, Faculty of Economic and Management, IPB University \\ Jl. Agatis, Campus IPB Dramaga Bogor 16680, Indonesia
}

\begin{abstract}
In running businesses and their operations, banks are required to earn profits. Profits earned by banks provide an added value for banks, especially for shareholders if the stock price increase. This research was conducted at 18 banks in BUKU II bank categories that already listed on the Indonesia Stock Exchange or Go Public. The purpose of this study was to determine factors influence profitability and stock returns banks in groups of BUKU II Go public. The study was conducted using secondary data from January 2014 to December 2018. In order to analyze the factors that influence firms' profitability and stock returns, data processed using panel data regression analysis. The results showed that significant factor affects profitability were total assets, non-performing loans (NPL), capital adequacy ratio (CAR), net interest margin (NIM), and the number of employees. Furthermore, a significant factor that affects stock returns is good corporate governance (GCG) and the number of electronic banking variations that are owned. The resulting research has managerial implications for the banks in maintaining several important financial ratios such as CAR, NPL, NIM, and also developing electronic banking and implementing GCG in every business process carried out.
\end{abstract}

Keywords: determinant factors, go public, panel data regression, profitability, stock return

\begin{abstract}
Abstrak: Dalam menjalankan bisnis dan operasinya, bank dituntut untuk memperoleh keuntungan. Keuntungan yang diperoleh bank memberikan nilai tambah bagi bank, khususnya bagi pemegang saham jika harga saham naik. Penelitian ini dilakukan pada 18 bank pada kategori BUKU II yang sudah terdaftar di Bursa Efek Indonesia atau Go Public. Tujuan penelitian ini dilakukan adalah untuk mengetahui faktor-faktor apa saja yang mempengaruhi profitabilitas dan return saham pada kelompok bank BUKU II Go public. Penelitian dilakukan dengan menggunakan data sekunder dari Januari 2014 sampai dengan Desember 2018. Untuk menganalisis faktor-faktor yang mempengaruhi profitabilitas dan return saham perusahaan, data diolah dengan menggunakan analisis regresi data panel. Hasil penelitian menunjukkan bahwa faktor signifikan yang mempengaruhi profitabilitas adalah total aset, kredit bermasalah (NPL), rasio kecukupan modal (CAR), marjin bunga bersih (NIM), dan jumlah karyawan. Selanjutnya faktor signifikan yang mempengaruhi return saham adalah good corporate governance (GCG) dan banyaknya variasi electronic banking yang dimiliki. Penelitian yang dihasilkan memberikan implikasi manajerial pentingnya bank untuk memperhatikan beberapa rasio keuangan penting seperti CAR, NPL, NIM serta melakukan pengembangan electronic banking dan penerapan GCG dalam setiap proses bisnis yang dilakukan.
\end{abstract}

Kata kunci: faktor penentu, go public, regresi data panel, profitabilitas, pengembalian saham

\footnotetext{
${ }^{1}$ Corresponding author:

Email: ferryard4@gmail.com
} 


\section{INTRODUCTION}

Facing the development of global dynamics and supporting Indonesia's economic growth in an optimal and sustainable manner, it is necessary to increase the level of resilience, competitiveness and efficiency of the national banking industry. These conditions led Bank Indonesia to issue Bank Indonesia Regulation No.14 / 26 / PBI / 2012 concerning Business Activities and Office Networks Based on Bank Core Capital. In Article 1 paragraph 4 the provision states that a commercial bank based on business activities, hereinafter referred to as BUKU, is a group of banks based on business activities adjusted to the level of their core capital. In Article 3 of this provision, the grouping of banks in Indonesia is regulated based on the level of their core capital, and the BUKU II bank group is a bank with a core capital level ranging from IDR one trillion to less than IDR five trillion.

Until June 2019, there were 59 banks in the BUKU II bank categories. Based on data obtained from the Indonesia Stock Exchange, there are 18 banks in BUKU II classified as public companies or listed in Indonesia Stock Exchange, and they have a variable core capital from IDR one trillion to under IDR five trillion. The following asset growth, loans and third party funds from banks in the BUKU II group, can be seen in Figure 1.

The performance achievements that occurred at the BUKU II Go Public Bank for the 2015-2018 period showed positive growth. BUKU II Go Public bank assets grew positively from 2015 to 2018. In 2016 assets grew by $11.67 \%$, in 2017 and 2018 grew by $9.35 \%$ and $6.62 \%$ respectively. Lending by the BUKU II Go Public bank during the 2015 to 2018 period showed positive growth. In 2016, loans provided by BUKU II Go Public banks grew by $8.13 \%$, and in 2017 decreased by $1.09 \%$. However, in 2018, credit was able to grow back to $8.81 \%$. Positive growth also occurred in the collection of third party funds carried out by BUKU II Go Public banks during the 2015 to 2018 period. In 2016, the third party funds collected managed to grow by $9.60 \%$. However, in 2017 the growth fell to $7.20 \%$ and in 2018 the growth of third party funds fell again to reach $2.64 \%$.

Furthermore, on the development of assets, credit and third party funds that occurred in BUKU II Go Public banks, operating income and operating expenses at BUKU II Go Public banks had growth that was not in line with the development of credit and third party funds in a certain period of time. In 2017 the BUKU II Go Public banks, third party fund collection was able to grow by $7.20 \%$, however the operating expenses that occurred in 2017 showed a decrease of $-2.30 \%$. Likewise, lending in 2017 was still able to grow by $1.09 \%$, however, operating income decreased by $-0.29 \%$. In 2018 there was also a condition where the collection of third party funds grew by only $2.64 \%$, but operating expenses at BUKU II banks grew by $6.56 \%$.

The development that occurred at the BUKU II Go Public bank requires a more in-depth analysis of how operational management affects the income and operating costs of the position from 2014 to 2018 of each bank in the BUKU II bank group. The variety of performance results that occur in banks in the BUKU II group cannot be separated from the results of the business and operational processes carried out by each bank. In running a business and its operations, banks are required to be able to run them efficiently. Efficiency carried out by banks will be able to provide results in the form of maximum profit or profit. Profits or profits owned will then provide added value for the bank, especially for shareholders, including an increase in share prices. This phenomenon encourages this research to be conducted to analyze the determinants factor affects banks in groups BUKU II from the perspective of practical banking applications and practices that will establish and ensure the sustainability of banking in Indonesia.

Research on profitability and stock return has been carried in Indonesia. An analysis of financial performance by comparing Islamic and conventional banks was also carried out by Muslich and Umardani (2016), using financial ratios: CAR, NPL / NPF, ROA, ROE, LDR / FDR, REO / BOPO. The data used are financial reports issued by Bank Indonesia (BI), annual reports released by banking companies listed on the Indonesia Stock Exchange (IDX), annual reports issued by Islamic banking companies that are not listed on the Indonesia Stock Exchange (IDX), and Indonesian banking supervision reports available at Bank Indonesia (BI) for the years 2005-2012. Six samples are used to compare the financial performance of Islamic banks with conventional banks and the method of analysis is the Independent T-test statistical test. The facts show that there are significant differences between each Islamic bank and conventional banks CAR, ROA, ROE, LDR / FDR, and OEOI, while there is no significant difference between NPL and NPF. 


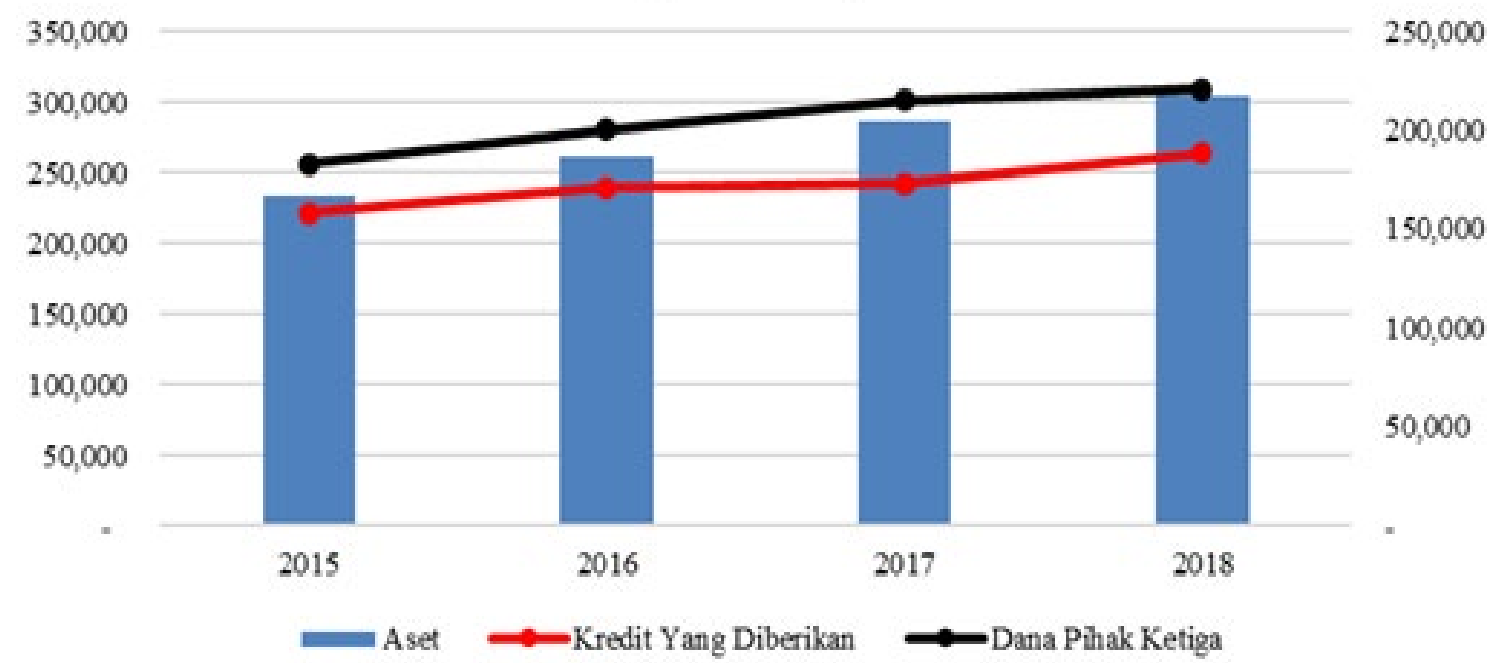

Figure 1. BUKU II Bank Performance Development

Analysis of determinants of factors that affect efficiency and profitability was also carried out by Subandi and Ghozali (2013). The purpose of this research is to estimate the factors that affect the level of bank technical efficiency as measured by nonparametric Data Envelopment Analysis (DEA) and its impact on profitability performance as measured by return on assets (ROA). This study applies a panel data regression model with a random effect approach to 110 conventional banks during 2006-2010. Based on the estimation of the determinants of the level of bank efficiency, it can be seen that the factors of bank size, type of bank, capital adequacy ratio, loan deposit ratio, operating costs and net interest margin significantly affect the level of technical efficiency. In a later stage, the estimation of the determinants of profitability shows that factors such as bank size, type of bank, nonperforming loans, loan deposit ratio, operating costs and net interest margin significantly affect ROA. This study has implications both theoretically and management. The theoretical implications for this research make important contributions to the development of theories of efficiency and financial performance. Finally, the managerial implications of this study have consequences for increasing efficiency and profitability performance, especially for domestic banks. Research on the analysis of factors that affect stock and portfolio returns in Indonesia has also been carried out, one of which is the analysis of the effect of market returns and several macroeconomic variables on individual and portfolio stock returns (comparison of market models, macro-economic models and their combinations) by Hasan (2010). In research conducted on cross-industry company stocks included in the LQ-45 index and the
Jakarta Islamic Index (JII), it was found that market returns, which are proxied by the Composite Stock Price Index (IHSG), have a positive and significant effect on individual and portfolio stock returns. The macroeconomic variables also have a significant effect on portfolio returns. In this case, the Bank Indonesia interest rate has a positive and significant effect on portfolio returns. In addition, inflation has a negative effect on portfolio returns and the exchange rate has a positive and significant effect on portfolio returns.

Based on the research that has been done, especially in Indonesia, there is currently no research that focuses on banking in Indonesia which is based on Bank Indonesia Regulation No.14 / 26 / PBI / 2012 concerning Business Activities and Office Networks Based on Bank Core Capital. this is the bank group in BUKU II. To fill in the gaps in this research, this research was conducted with a focus on banks in the BUKU II group that have gone public or listed on the Indonesia Stock Exchange with the analysis period of 2014-2018. To achieve the expected level of profit, efforts are required from the bank to be able to manage the factors that influence it. For the banking sector, if the profit increases, it will be able to increase the added value for the bank and for shareholders an increase in the share price.

The performance development that occurred at the BUKU II Go Public bank raises several questions related to how best to manage the company, namely what factors affect profitability and bank stock returns in the Go Public BUKU II group? The research objective here is to analyze the factors that can significantly influence profitability and stock returns in generating 
revenue optimization and then to support sustainable income levels. The specific objective of this study is to analyze the factors that affect the profitability and return of shares in the BUKU II Go Public banks in Indonesia.

\section{METHODS}

Based on the Financial Services Authority Circular Letter Number 14 / SEOJK.03 / 2017 Concerning the Rating of Commercial Banks, conventional commercial banks are required to conduct a rating of bank soundness using a risk-based bank rating. The assessment should discuss (a) the bank's risk profile, (b) good corporate governance (GCG), (c) profitability, and (d) capital. Naceur (2003) examines the determinants of profitability in the bank industry in Tunisia, and divided them into two main categories, namely internal determinants (liquidity, capital adequacy, and management costs) and external determinants (ownership, company size, and economic conditions). The findings of the study indicate that efficient cost management is one of the most significant factors in obtaining a high level of bank profitability. Economic conditions are macro indicators, for example, inflation has a positive effect on profitability and if interest rates are high then a bank's profitability is low.

In accordance with the objectives of this study, an analysis was carried out of the internal and external factors that affect the profitability and stock returns of the 18 banks in the BUKU II Go Public Bank group for the period from 2014 to 2018 . This was done in order to find out what internal and external factors influence them. The internal factors that are used in this study have been divided into two, namely financial and non-financial aspects: 1) Internal factors, financial aspects, namely: Total amount of assets owned, Nonperforming loan or non-performing financing ratio or non-performing loans or financing ratio, The capital adequacy ratio or minimum capital adequacy ratio, The loan to deposit ratio or the ratio of loans or financing disbursed compared to third-party funds that have been collected, The ratio of the net interest margin or the net rewards or the ratio between the interest income or margin or profit sharing and average earning assets; 2) Internal factors, non-financial aspects, namely: The value of good corporate governance, namely the value of the results of the implementation of good corporate governance when a self-assessment is conducted, The number of types or variations of electronic banks owned, The size of the total office network, including the head office, regional offices, branch offices, subbranch offices, and cash offices, The number of automated teller machines or ATMs owned, The number of employees, including the number of permanent employees and contract employees, The number of management employees including commissioners and directors; 3) External factors, namely: The growth in the money supply, The inflation rate ratio, The exchange rate growth, Economic growth.

The statistical technique used for the relationship analysis is panel data analysis. According to Widarjono (2007), the use of panel data analysis has several advantages. First, the panel data, which is a combination of two-time series data and a cross section, is able to provide more data so that it will produce a greater degree of freedom. Second, combining information from time series data and from cross sections can overcome problems that arise when there are omittedvariable problems.

To find out the internal and external factors that influence the scale of efficiency, a panel data regression analysis was used. The panel data regression analysis was chosen because it is accords with the objectives and characteristics of the data held. Panel data regression is a combination of cross section data and time series data, and the same cross section units are measured at different times. In other words, the panel data is data from some of the same individuals that were observed during a certain period of time. If we have a time period $\mathrm{T}(\mathrm{t}=1,2, \ldots, \mathrm{T})$ and we have $\mathrm{N}$ number of individuals $(i=1,2, \ldots, N)$, then with panel data we will have a total observation unit of NT. The results of the panel data regression analysis are divided into two parts, namely for the efficiency of the intermediary approach and for the efficiency of the production approach.

The panel data regression model for analyzing the effects of internal and external factors for profitability and the level of stock returns is as follows:

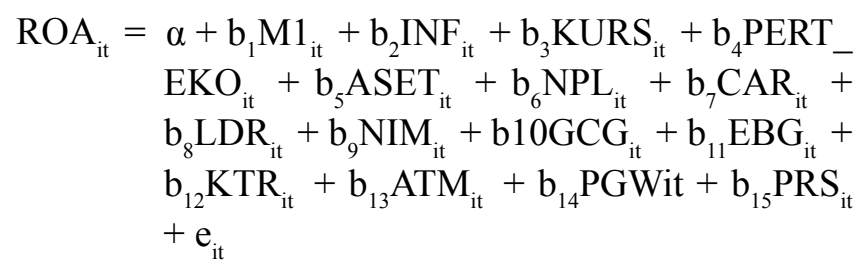




$$
\begin{aligned}
\mathrm{RSH}_{\mathrm{it}}= & \alpha+\mathrm{b}_{1} \mathrm{M}_{\mathrm{it}}+\mathrm{b}_{2} \mathrm{INF}_{\mathrm{it}}+\mathrm{b}_{3} \mathrm{KURS}_{\mathrm{it}}+\mathrm{b}_{4} \mathrm{PERT}_{-} \\
& \mathrm{EKO}_{\mathrm{it}}+\mathrm{b}_{5} \mathrm{ASET}_{\mathrm{it}}+\mathrm{b}_{6} \mathrm{NPLit}+\mathrm{b}_{7} \mathrm{CAR}_{\mathrm{it}}+ \\
& \mathrm{b}_{8} \mathrm{LDR}_{\mathrm{it}}+\mathrm{b}_{9} \mathrm{NIM}_{\mathrm{it}}+\mathrm{b}_{10} \mathrm{GCG}_{\mathrm{it}}+\mathrm{b}_{11} \mathrm{EBG}_{\mathrm{it}}+ \\
& \mathrm{b}_{12} \mathrm{KTR}_{\mathrm{it}}+\mathrm{b}_{13} \mathrm{ATM}_{\mathrm{it}}+\mathrm{b}_{14} \mathrm{PGW}_{\mathrm{it}}+\mathrm{b}_{15} \mathrm{PRS}_{\mathrm{it}}+ \\
& \mathrm{e}_{\mathrm{it}}
\end{aligned}
$$

Where: $\mathrm{ROA}_{\mathrm{it}}$ (Value of the ratio of return on assets for a certain period of time), $\mathrm{RSH}_{\mathrm{it}}$ (Value of the return on a certain period of stock), $\mathrm{M} 1_{\mathrm{it}}$ (Percentage of growth in the money supply), $\mathrm{INF}_{\text {it }}$ (Percentage of inflation for a certain period), $\operatorname{KURS}_{\mathrm{it}}$ (Percentage change in the exchange rate of the rupiah against the US dollar for a certain period of time), PERT_EKO ${ }_{\text {it }}$ (Percentage of Indonesia's economic growth during a certain period of time), $\operatorname{ASET}_{\text {it }}$ (BUKU II Go Public bank's total assets for a certain period of time), $\mathrm{NPL}_{\mathrm{it}}$ (NPL or NPF percentage of the BUKU II Go Public banks for a certain period of time), $\mathrm{CAR}_{\text {it }}$ (CAR percentage of the BUKU II Go Public banks during a certain period) $\mathrm{LDR}_{\mathrm{it}}$ (LDR or FDR percentage of the BUKU II Go Public banks during a certain period of time), NIM $_{\mathrm{it}}$ (NIM or NI percentage for the BUKU II Go Public banks for during a certain period of time), $\mathrm{GCG}_{\mathrm{it}}$ (Level of bank soundness good corporate governance for during a certain period of time), $\mathrm{EBG}_{\mathrm{it}}$ (Number of types of electronic banking owned by the BUKU II Go Public banks for during a certain period of time), $\mathrm{KTR}_{\mathrm{it}}$ (Number of office networks owned by BUKU II banks going public for a certain period of time), ATM $_{\text {it }}$ (Number of ATM Machines self-owned by BUKU II Go Public banks for a certain period of time), $\mathrm{PGW}_{\text {it }}$ (Number of BUKU II Go Public bank employees for during a certain period of time), $\mathrm{PRS}_{\text {it }}$ (Number of bank management employees for BUKU II Go Public banks from during a certain period of time), $\alpha$ (Constant), $b(1 \ldots 17)$ (Regression coefficient for each independent variable), e (Error term), t (Time), i (Bank BUKU II Go Public).

This research was conducted from June to December 2019 for 18 banks in the BUKU 2 categories in Indonesia that had been listed or had decided to go public. The study was conducted in Jakarta using secondary data within a range of years from 2014 to 2018. As for the object of research, it was the 18 banks in BUKU 2 in Indonesia that had been listed or had decided to go public.

\section{RESULTS}

\section{The Determinants of Profitability}

The results of the analysis for the common effect model in Table 1 shows that there are five variables that have a significant effect at the 5\% significance level of profitability, namely, total assets with a coefficient of 1.05E-07, non-performing loans (NPL) or non-performing financing (NPF) with a coefficient of -0.592025 , the capital adequacy ratio (CAR) with a coefficient of 0.053174 , the net interest margin (NIM) or net rewards with a coefficient of 0.554814 , and the number of employees with a coefficient of -0.000639 . The accuracy of the model generated by the common effect model was $83.22 \%$.

Based on tests conducted, it was found that the best model for analyzing the internal and external factors that influence efficiency with an intermediation approach is the common effect model, with the following functions:

$$
\begin{aligned}
& \mathrm{ROA}_{\mathrm{it}}=-172.0270+0.923746 \mathrm{M} 1_{\mathrm{it}}+1.624314 \mathrm{INF}_{\mathrm{it}}+ \\
& 0.701679 \text { KURS }_{\text {it }}+{ }_{29.59984 P E R T} \\
& \mathrm{EKO}_{\mathrm{it}}+1.05 \mathrm{E}-07 \mathrm{ASET}_{\mathrm{it}}-0.592025 \mathrm{NPL}_{\mathrm{it}}+ \\
& 0.053174 \mathrm{CAR}_{\mathrm{it}}+0.013831 \mathrm{LDR}_{\mathrm{it}}+ \\
& 0.554814 \mathrm{NIM}_{\mathrm{it}}+0.236574 \mathrm{GCG}_{\mathrm{it}}- \\
& 0.120845 \mathrm{EBG}_{\mathrm{it}}+0.002325 \mathrm{KTR}_{\mathrm{it}}+ \\
& 0.002138 \mathrm{ATM}_{\mathrm{it}}-0.000639 \mathrm{PGW}_{\mathrm{it}}- \\
& 0.013390 \mathrm{MJM}_{\text {it }}+\mathrm{e}_{\mathrm{it}}
\end{aligned}
$$

The number of factors that affect profitability in terms of the return on assets (ROA) is four, namely, the total assets owned, non-performing loans (NPL) or nonperforming financing (NPF), the capital adequacy ratio (CAR), the net interest margin (NIM) ) or net rewards, and the number of employees. The credit or financing provided by banks to customers, in addition to providing income, also causes losses in the form of credit risk, which for banks is due to the inability of customers to meet their obligations. The greater the inability of customers to meet their obligations, the higher the ratio of non-performing loans (NPL) or nonperforming financing (NPF) will be. A high NPL ratio will cause an increase in the amount of loss reserves that must be formed by banks. These reserves must be established in accordance with the quality of the credit or financing provided, and the worse the quality, the greater the amount of reserves that will be needed, and vice versa. The greater the size of the reserve formed by the bank, the greater in size that the operational 
costs or expenses of the bank will be, and so the profit derived by the bank will decrease. The effect of NPL on profitability is also in accordance with research conducted by Berger and De Young (1997), who conducted research that examined four hypotheses regarding the relationship between loan quality, cost efficiency, and bank capital. The data shows that nonperforming loans precede measured reductions in cost efficiency, that the measured cost efficiency precedes the reduction of problem loans, and that a reduction in capital in small capital banks precedes an increase in problem loans. Therefore, cost efficiency can be an important indicator of there being problem loans and problem banks.

The impact of NPL on profitability was studied by Haneef et al. (2012), who conducted research on five banks in Pakistan, and the results of their study revealed that there is no appropriate mechanism for risk management in the Pakistani banking sector.
The study also concluded that the number of problem loans increased due to a lack of risk management that threatened bank profitability. The influence of NPLs on bank performance has also been studied by Chimkono et al. (2016), who looked at banks in Malawi, with the result that the ratio of bad loans, cost efficiency ratios, and average loan interest rates was found to have a significant effect on bank performance in Malawi. The impact of the NPL on profitability is also consistent with research conducted by Karim et al. (2010), who studied banks in Malaysia and Singapore, and found that higher bad credit results reduced cost efficiency. Likewise, a lower cost efficiency increases bad credit. Research conducted by Vithessonthi (2016) on 82 publicly listed commercial banks in Japan during the period from 1993 to 2013 found different results: credit growth and bad credit did not affect profitability. Overall, the findings show that while increasing the supply of bank loans increases the level of bad loans, it does not lead to a higher level of profitability.

Table 1. Results of common effect model profitability

\begin{tabular}{|c|c|c|c|c|c|}
\hline \multicolumn{2}{|l|}{ Variable } & Coefficient & Std. Error & t-Statistic & Prob. \\
\hline \multicolumn{2}{|l|}{ Asset } & $1.05 \mathrm{E}-07$ & $3.71 \mathrm{E}-08$ & 2.832116 & $0.0060 * *$ \\
\hline \multicolumn{2}{|l|}{ Non Performing Loan } & -0.592025 & 0.076957 & -7.692980 & $0.0000 * *$ \\
\hline \multicolumn{2}{|c|}{ Capital Adequacy Ratio } & 0.053174 & 0.021500 & 2.473261 & $0.0158 * *$ \\
\hline \multicolumn{2}{|l|}{ Loan to Deposit Ratio } & 0.013831 & 0.011000 & 1.257321 & 0.2128 \\
\hline \multicolumn{2}{|l|}{ Net Interest Margin } & 0.554814 & 0.123581 & 4.489466 & $0.0000 * *$ \\
\hline \multicolumn{2}{|c|}{ Good corporate governance } & 0.236574 & 0.423248 & 0.558950 & 0.5780 \\
\hline \multicolumn{2}{|c|}{ Number of types of electronic banking } & -0.120845 & 0.201641 & -0.599309 & 0.5509 \\
\hline \multicolumn{2}{|c|}{ Number of office networks } & 0.002325 & 0.006026 & 0.385756 & 0.7008 \\
\hline \multicolumn{2}{|c|}{ Number of ATM Machines } & 0.002138 & 0.003481 & 0.614260 & 0.5410 \\
\hline \multicolumn{2}{|c|}{ Number of bank employees } & -0.000639 & 0.000323 & -1.979417 & $0.0517 * *$ \\
\hline \multicolumn{2}{|c|}{ Number of bank management } & -0.013390 & 0.104013 & -0.128733 & 0.8979 \\
\hline \multicolumn{2}{|c|}{ Growth of money supply } & 0.923746 & 1.353556 & 0.682458 & 0.4972 \\
\hline \multicolumn{2}{|l|}{ Inflation rate } & 1.624314 & 2.042947 & 0.795084 & 0.4293 \\
\hline \multicolumn{2}{|l|}{ Exchange rate } & 0.701679 & 0.944516 & 0.742898 & 0.4600 \\
\hline \multicolumn{2}{|l|}{ Economic growth } & 29.59984 & 42.98033 & 0.688683 & 0.4933 \\
\hline \multicolumn{2}{|l|}{$\mathrm{C}$} & -172.0270 & 243.2649 & -0.707159 & 0.4818 \\
\hline R-squared & 0.832150 & \multicolumn{2}{|c|}{ Mean dependent var } & 0.806279 & \\
\hline Adjusted R-squared & 0.796182 & \multicolumn{2}{|c|}{ S.D. dependent var } & 2.990533 & \\
\hline S.E. of regression & 1.350112 & \multicolumn{2}{|c|}{ Akaike info criterion } & 3.604492 & \\
\hline Sum squared resid & 127.5961 & \multicolumn{2}{|c|}{ Schwarz criterion } & 4.061115 & \\
\hline Log likelihood & -138.9932 & \multicolumn{2}{|c|}{ Hannan-Quinn criter. } & 3.788262 & \\
\hline F-statistic & 23.13594 & \multicolumn{2}{|c|}{ Durbin-Watson stat } & 2.040910 & \\
\hline Prob(F-statistic) & 0.000000 & & & & \\
\hline
\end{tabular}

$(* *)=$ Significant level $\alpha=5 \%(0.05) ;(*)=$ Significant level $\alpha=10 \%(0.1)$ 
The bank as a financial institution is always able to obtain more income from lending or financing, with lower costs coming from third-party funds or from demand deposits. In addition to obtaining income from lending or financing, banks also make other forms of investments, such as purchasing securities issued by both government and non-government entities, such as corporations, placements with other banks, and other forms of investment. These efforts are carried out in order to obtain income for the sake of optimizing thirdparty funds obtained from the public. The greater the bank's income that is obtained from credit, financing, and other investments, the more it will have an impact on increasing the net interest margin (NIM), which shows that the profit or profitability of the bank is also getting bigger.

The results of the analysis carried out show that the effect of assets on profitability is quite small. This is because the assets at the bank in general consist of credit or financing, securities owned, loss reserves, fixed assets, productive assets and other assets. Each of these asset groups has different levels of income, with the largest income coming from lending or financing. The bank will attempt to channel the third-party funds that have been collected by the bank into credit or financing. This is done because the income earned from credit or financing is greater than from the placement in other forms of assets. An increase in the amount of assets owned by the bank will also lead to increase in the amount of credit or financing that is provided to customers, which will have an impact by increasing bank revenues and profits.

In carrying out the functions of raising funds and channeling credit or financing, the bank needs employees or reliable human resources. The needs of employees in banks are generally divided into two parts, namely, business and business support. Both need and support each other in order to improve the bank's performance. Along with the growing business and operations that are provided to customers, the bank is required to have an adequate number of employees. The greater the number of employees, the greater the amount of additional labor costs that a bank will certainly have, which will reduce the amount of profits or benefits obtained. To be able to improve the bank's performance, the employees need to be given an attractive education, training, and remuneration, so as to increase their productivity. The greater the number of employees, the greater the burden or costs that are required for education and training will be.

By lending or financing, banks can obtain income from the payment of obligations by customers, but banks are also faced with a credit risk due to the potential inability of customers to meet their obligations. In addition to this credit risk, banks are also expected to face several other risks from the business and operational activities that they carry out. For the risks that arise, the bank must provide and have a sufficient amount of capital, which is known as the minimum capital requirement (KPMM) or the capital adequacy ratio (CAR). The greater the amount of capital owned by the bank, the more the bank has an ability to extend credit or financing and offer other operational services. This will certainly have an impact on increasing the amount of the bank revenue that comes from credit or financing and other income, which means that the bank will be also able to increase bank profits. The effect of the CAR on profitability is in line with the research conducted by Olalekan and Adeyinka (2013), who studied banks in Nigeria. The findings for the primary data analysis reveal an insignificant relationship, but the secondary data analysis shows a positive and significant relationship between capital adequacy and bank profitability. This implies that for the banks that take deposits in Nigeria, capital adequacy plays a key role in determining their level of profitability. It was found that capitalization and profitability are indicators of bank risk management efficiency and this provides a cushion against losses that are not covered by current income. Similar results were also produced by Abusharba et al. (2013), who conducted research on Islamic banking in Indonesia during the period from 2009 to 2011. They found that profitability and liquidity were positively related to the capital adequacy requirements. Meanwhile, the amount of uncollected funds measured by non-performing financing (NPF) are significant but negatively related to the capital adequacy ratio. The effect of capital adequacy on profitability was also obtained from research conducted by Naceur and Goaied (2008) on banks in Tunisia in the period from 1980 to 2000 . The results showed that high net interest margins and profitability tend to be associated with banks that have a relatively high amount of capital with large overhead costs. 


\section{The Determinants of Stock Return}

The results of the analysis for the fixed effect model are shown in Table 2., and they show that there are two variables that have a significant effect on stock returns, namely the self-assessment value of good corporate governance (GCG), with a coefficient of -163.2619, and the number of variations or variations of electronic banking that are owned, with a coefficient of 75.39541 at a $5 \%$ real level. The accuracy of the model produced by the fixed effect model for the efficiency analysis with an intermediation approach is $38.49 \%$.

Based on the tests conducted, it was found that the best model for analyzing the internal and external factors that affect efficiency with the intermediation approach is the fixed effect model, with the following functions:

$$
\begin{aligned}
& \mathrm{RSH}_{\mathrm{it}}=-13801.00+86.87394 \mathrm{M}_{\mathrm{it}}+135.7872 \mathrm{INF}_{\mathrm{it}} \\
& +56.90690 \mathrm{KURS}_{\mathrm{it}}+2453.525 \mathrm{PERT} \\
& \mathrm{EKO}_{\mathrm{it}}-1.21 \mathrm{E}-06 \mathrm{ASET}_{\mathrm{it}}-5.153044 \mathrm{NPL}_{\mathrm{it}} \\
& +\quad 2.099306 \mathrm{CAR}_{\mathrm{it}}-0.453754 \mathrm{LDR}_{\mathrm{it}} \\
& +14.90013 \text { NIM }_{\mathrm{it}}-163.2619 \mathrm{GCG}_{\mathrm{it}}+ \\
& 75.39541 \mathrm{EBG}_{\mathrm{it}}-0.788466 \mathrm{KTR}_{\mathrm{it}}+ \\
& 0.779893 \mathrm{ATM}_{\mathrm{it}}-0.030802 \mathrm{PGW}_{\mathrm{it}}- \\
& \text { 17.15754MJM } \mathrm{M}_{\mathrm{it}}+\text { eit }
\end{aligned}
$$

As for factors that affect stock returns, there are three, namely, the total assets owned, the value of the selfassessment of good corporate governance, and the number of electronic banking variations. Currently, banks are faced with a level of competition in serving customer financial transactions. In the current industry 4.0 era, banking is also done in the form of developing information technology. Banks can create various distribution channels or delivery channels for customers to be able to conduct financial transactions by electronic banking. The various types of electronic banking developed by banks range from phone banking to digital banking. Electronic banking is developed to create a higher level of efficiency, which should ultimately increase bank revenues and profits. In the end, for banks that have gone public, the benefits obtained will provide a fairly large dividend for shareholders. Banks that are able to develop a variety of electronic banking options at this time can also use them for promotional media. A positive response from customers who use electronic banking will improve the reputation of the bank, which will indirectly also increase the bank's stock price.
Banks are intermediary institutions that look to collect of funds and perform the lending or financing, and if they do their activities well, they will get the trust of the public. This public includes investors and community members who are shareholders of the banks that have gone public. The main purpose of a company, including banks, is to provide added value and increase the wealth of shareholders. Investors or shareholders have a desire that the bank can carry out its intermediation function properly, and they also have a desire that they carry out these functions by applying the principles of good corporate governance or good governance and risk management. The behavior of investors who are concerned about the implementation of good corporate governance in banking is in accordance with research conducted by Zulkafli and Samad (2007), which found that countries in Asia have implemented corporate governance reforms to enhance the protection of the interests of shareholders and stakeholders. Such reforms have affected the business behavior of all companies in the region because they allow for greater amount of monitoring, especially by shareholders. This study analyzes the corporate governance of banking companies listed in nine Asian emerging markets. The results showed that there were differences in the monitoring mechanisms of banking companies and non-bank companies. It is important for banks to set out strategic objectives and a company ethos as well as have clear governance and risk management. It is also important to communicate the policies to all units in the bank. Banks that do not have strategic objectives will find it difficult to manage their activities because the use of resources become unfocused. With the implementation of good corporate governance, banks will be able to conduct business in accordance with clearly defined values. In the end, the banks that do so will be able to increase the value of the company and see rising share prices.

Research on the influence of the implementation of good corporate governance on banking performance has also been carried out by Ene and Alem (2016) concerning banks in Nigeria. The study revealed that the relationship between corporate governance and bank performance in Nigeria is quite significant as a unit change in the board size and the relative size of nonexecutive directors increases the return on assets. The study therefore concludes that proper structuring of the stakeholders in the corporate governance team is a panacea to the perennial banking crisis experienced in Nigeria. It was recommended among others that 
banking sector should engage in strategic training of board members and senior bank managers especially in areas that promote internal control effectiveness, board structure and independence and in banking ethics. Similar results were also obtained from research conducted by Mang'unyi (2011), who explored the structure of ownership and corporate governance and its effect on banks' performance in Kenya. The study revealed that there were no significant differences between the types of ownership and financial performance, and between the structure of bank ownership and corporate governance practices. Further, the results reveal that there are significant differences between the types of corporate governance and bank financial performance. However, foreign-owned banks performed slightly better than domestic-owned banks. This study recommends corporate entities to promote corporate governance in order to send positive signals to potential investors. The importance of implementing good corporate governance has also been researched by Hani (2014) in terms of Lebanese banking during the period from 2006 to 2010 . The results revealed a positive effect for a higher concentration of insider ownership on the returns of Lebanese banks, which showed that the higher the number of shares held by insiders, the better their performance. The weakness of corporate governance in some Lebanese banks is compensated for by a higher concentration of insider ownership. The importance of implementing good corporate governance has also been studied in Nigeria by Nworji et al. (2011), who investigated the problems, challenges, and opportunities related to corporate governance and bank failures in Nigeria. They were looking to see if there is a significant relationship between corporate governance and bank failures. The results show that corporate governance is necessary for the functioning of banks and that corporate governance can prevent bank pressure only if it is properly implemented.

Table 2. Results of fixed effect stock return

\begin{tabular}{|c|c|c|c|c|c|}
\hline \multicolumn{2}{|l|}{ Variable } & Coefficient & Std. Error & t-Statistic & Prob. \\
\hline \multicolumn{2}{|l|}{ Asset } & $-1.21 \mathrm{E}-06$ & $6.00 \mathrm{E}-06$ & -0.202358 & 0.8404 \\
\hline \multicolumn{2}{|l|}{ Non Performing Loan } & -5.153044 & 7.416636 & -0.694795 & 0.4903 \\
\hline \multicolumn{2}{|c|}{ Capital Adequacy Ratio } & 2.099306 & 2.605292 & 0.805785 & 0.4241 \\
\hline \multicolumn{2}{|c|}{ Loan to Deposit Ratio } & -0.453754 & 1.721643 & -0.263558 & 0.7932 \\
\hline \multicolumn{2}{|l|}{ Net Interest Margin } & 14.90013 & 26.29931 & 0.566560 & 0.5735 \\
\hline \multicolumn{2}{|c|}{ Good corporate governance } & -163.2619 & 70.98450 & -2.299966 & $0.0256 * *$ \\
\hline \multicolumn{2}{|c|}{ Number of types of electronic banking } & 75.39541 & 29.73876 & 2.535258 & $0.0143 * *$ \\
\hline \multicolumn{2}{|c|}{ Number of office networks } & -0.788466 & 1.673272 & -0.471212 & 0.6395 \\
\hline \multicolumn{2}{|c|}{ Number of ATM Machines } & 0.779893 & 1.181787 & 0.659927 & 0.5123 \\
\hline \multicolumn{2}{|c|}{ Number of bank employees } & -0.030802 & 0.081426 & -0.378283 & 0.7068 \\
\hline \multicolumn{2}{|c|}{ Number of bank management } & -17.15754 & 15.42811 & -1.112096 & 0.2713 \\
\hline \multicolumn{2}{|c|}{ Growth of money supply } & 86.87394 & 119.6529 & 0.726050 & 0.4711 \\
\hline \multicolumn{2}{|l|}{ Inflation rate } & 135.7872 & 182.0908 & 0.745711 & 0.4593 \\
\hline \multicolumn{2}{|l|}{ Exchange rate } & 56.90690 & 83.31776 & 0.683010 & 0.4977 \\
\hline \multicolumn{2}{|l|}{ Economic growth } & 2453.525 & 3765.844 & 0.651521 & 0.5176 \\
\hline \multicolumn{2}{|l|}{$\mathrm{C}$} & -13801.00 & 21373.91 & -0.645694 & 0.5214 \\
\hline R-squared & 0.384871 & \multicolumn{2}{|c|}{ Mean dependent var } & 22.32321 & \\
\hline Adjusted R-squared & -0.001092 & \multicolumn{2}{|c|}{ S.D. dependent var } & 107.8569 & \\
\hline S.E. of regression & 107.9157 & \multicolumn{2}{|c|}{ Akaike info criterion } & 12.48730 & \\
\hline Sum squared resid & 593936.1 & \multicolumn{2}{|c|}{ Schwarz criterion } & 13.44227 & \\
\hline Log likelihood & -491.4667 & \multicolumn{2}{|c|}{ Hannan-Quinn criter. } & 12.87119 & \\
\hline F-statistic & 0.997172 & \multicolumn{2}{|c|}{ Durbin-Watson stat } & 2.468199 & \\
\hline Prob(F-statistic) & 0.493777 & & & & \\
\hline
\end{tabular}

$(* *)=$ Significant level $\alpha=5 \%(0.05) ;(*)=$ Significant level $\alpha=10 \%(0.1)$ 


\section{Managerial Implications}

The results of the analysis of internal and external factor variables that have a significant effect on profitability show that there are five factors consisting of total assets, Non Performing Loan (NPL) or Non Performing Financing (NPF), Capital Adequacy Ratio (CAR), Net Interest Margin (NIM) and number of employees or employees. In response to this, the managerial implication for BUKU II Go Public banks is the importance of having good resources in the form of assets or employees. The number of employees owned in accordance with the development of the business along with adequate capabilities and expertise can be one of the steps to increase profits. In human resource management, banks need to pay attention to the ratio of profit to the number of employees. This is important because employees as assets have a role in generating income for the bank. The development of innovation needs to be carried out by BUKU II Go Public banks, both in products of raising funds and lending or financing. One form that can be taken is the development of electronic banking both internally and working with third parties, one of which is financial technology or fintech. These efforts were made so that banks can obtain a fairly high Net Interest Margin (NIM).

The implementation of risk management in banking is very important in creating a healthy and integrated banking industry, so that the bank's business is carried out in a risk corridor that remains controlled. The implementation of orderly risk management at each bank will in turn create a healthier industry, one of which is the low ratio of Non-Performing Loans (NPL) or Non-Performing Financing (NPF). Even though the bank has tried to manage the risks it faces, the bank cannot avoid various unexpected events. To cover this, after mitigation efforts are made, banks must prepare capital to absorb losses due to the bank's residual risk from business and operational activities. For this reason, it is important for BUKU II Banks to Go Public to always have sufficient capital. The Capital Adequacy Ratio (CAR) is an important indicator to measure the capital owned by a bank to be able to cover the risks faced by the bank.

The results of the analysis of internal and external factor variables that have a significant effect on stock returns show that there are two factors consisting of the self-assessment value of good corporate governance and the number of variations or types of electronic banking owned by banks. Bank BUKU II Go Public, apart from being a financial service institution it is also a publicly owned institution, in this case investors who become shareholders are expected to be able to live up to the principles of good corporate governance. The principles of disclosure of information, accountability, responsibility, independence and equality in every business process must be implemented. Investors who become shareholders hope that the implementation of good corporate governance will enable banks to continue to be able to compete with other banks. In the current industrial era 4.0, it is imperative for banks to continuously develop and create various product and service innovations. The competition faced by BUKU II Go Public banks is not only among banks, but also with financial technology companies. The development of various electronic banking services and the application of digital banking in various business and operational processes is a must. Collaborating or collaborating with third parties in creating variations and varieties of electronic banking can be an option in the midst of limited resources. Products and services developed must be able to meet all segments that are the target market for the bank

\section{CONCLUSIONS AND RECOMMENDATIONS}

\section{Conclusions}

Factors that affect profitability are total assets, Non Performing Loans (NPL), Capital Adequacy Ratio (CAR), Net Interest Margin (NIM) and number of employees. Increasing bank profitability can be done by increasing total assets owned by placing in productive assets that have high income, maintaining credit or financing quality by keeping the NPL ratio as low as possible, increasing capital owned (CAR) to be able to support business growth and cover risks. that happened. Other efforts that can be made are increasing the NIM through the collection of low-cost funds and channeling credit or financing to businesses that provide high income, as well as optimizing the number of employees by evaluating the resulting productivity. Factors affecting stock returns are Good Corporate Governance (GCG) and the number of variations or types of electronic banking owned. For banks that have gone public, the implementation of good corporate governance will be able to increase stock returns. In 
addition, today's banks are also required to be able to innovate by developing various variations or types of electronic banking they have.

\section{Recommendations}

In order to achieve the expected increase in profitability, BUKU II GO Public banks in managing banks need to pay attention to several things, namely credit quality management by maintaining the ratio of Capital Adequacy Ratio (CAR) and Non Performing Loans (NPL). In addition, it is necessary to increase Net Interest Margin (NIM) by means of raising cheap funds and channeling funds with high margins and low risks, such as financing to MSMEs and consumer financing. In line with the development of the current era of disruption, and in order to increase share prices, the BUKU II Go Public Bank is expected to be able to develop electronic banking by creating various product and service innovations in order to increase the range of services to customers. As well as implementing Good Corporate Governance (GCG) by taking into account the aspects of disclosure of information, accountability, responsibility, independence and equality in every business process carried out. For further research can be done to identify other external and internal factors that have an impact on profitability and stock returns.

\section{REFERENCES}

Abusharba MT, Triyuwono I, Ismail M, Rahman AF. 2013. Determinants of Capital Adequacy Ratio (CAR) in Indonesian Islamic Commercial Banks. Global Reviews of Accounting and Finance 4(1):159-170.

Berger AN, De Young R. 1997. Problem Loans and Cost Efficiency in Commercial Banks. Journal of Banking \& Finance 21(6): 849-870.

Chimkono M, Njeru. 2016. Effect Of Non-Performing Loans And Other Factors On Performance Of Commercial Banks In Malawi. International Journal of Economics, Commerce and Management IV(2): 549-563.

Ene EE, Alem IEB. 2016. The Effect of Corporate Governance on Bank's Financial Performance in Nigeria. IOSR Journal of Business and Management 8(11): 99-107.

Financial Services Authority, 2018. Http://www.ojk. go.id, Indonesian Banking Statistics.

Haneef S, Riaz T, Ramzan M, Rana MA, Ishaq HM,
Karim Y. 2012. Impact of Risk Management on Non-Performing Loans and Profitability of Banking Sector of Pakistan. International Journal of Business and Social Science 3(7): 307-315.

Hani EC. 2014. The Impact Of Corporate Governance On The Performance Of Lebanese Banks. The International Journal of Business and Finance Research 8(5): 35-46.

Hasan. 2010. Analysis of the Influence of Market Returns and Several Macroeconomic Variables on Returns of Individual and Portfolio Shares. Access: Journal of Economics and Business 5(April 9): 97-107.

Karim MZA, Chan SG, Hassan S. 2010. Bank Efficiency And Non-Performing Loans: Evidence From Malaysia And Singapore. Prague Economic Papers 2010(2):118-132.

Mang'unyi EE. 2011. Ownership Structure and Corporate Governance and Its Effects on Performance: A Case of Selected Banks in Kenya. International Journal of Business Administration 2(3): 2-18.

Muslich A, Umardani D. 2016. Comparative Analysis of the Financial Performance of Islamic Banks and Conventional Banks in Indonesia. Journal of Service Management and Marketing 9(1): 129-156.

Naceur SB. 2003. The Determinants of the Tunisian Banking Industry Profitability: Panel Evidence. Universite Libre de Tunis Working Papers (ERF Research Fellow).

Naceur SB, Goaied M. 2008. The Determinants of Commercial Bank Interest Margin and Profitability: Evidence from Tunisia. Frontiers in finance and economics 5(1): 106-130.

Nworji ID, Adebayo O, David AO. 2011. Corporate Governance and Bank Failure in Nigeria: Issues, Challenges and Opportunities. Research Journal of Finance and Accounting 2(2):1-18.

Olalekan A, Adeyinka S. 2013. Capital Adequacy And Banks' Profitability: An Empirical Evidence From Nigeria. American International Journal of Contemporary Research 3(10):87-93.

Subandi, Ghozali I. 2013. Determinants of Efficiency and Its Impact on the Profitability Performance of the Banking Industry in Indonesia. Journal of Finance and Banking 17 (1): 123-135.

Vithessonthi C. 2016. Deflation, Bank Credit Growth, and Non-Performing Loans: Evidence from Japan. International Review of Financial 
Analysis 45: 295-305.

Widarjono A. 2007. Econometrics Theories and Applications for Economics and Business (2nd ed). Yogyakarta: Ekonisia FE UII.
Zulkafli AH, Samad FA. 2007. Corporate Governance and Performance of Banking Firms: Evidence from Asian Emerging Markets. Issues in Corporate Governance and Finance 2007: 4974. 